\title{
Program terpadu penanggulangan kemiskinan di Kota Surabaya
}

\author{
Integrated program design to overcome poverty in Surabaya
}

\author{
Erna Setijaningrum
}

\author{
Departemen Administrasi Negara \\ Fakultas Ilmu Sosial dan Ilmu Politik, Universitas Airlanga \\ Jalan Airlangga 4-6 Surabaya 60286, Indonesia. E-mail: erna_set@yahoo.com \\ Telepon: (031) 5034015
}

\begin{abstract}
Surabaya is one of metropolitan city in Surabaya, yet still has a high poverty rates. This research aims to design an integrated program in reducing poverty in Surabaya. The high poverty rates lead to several complex problems such as unemployment, education, health, crime and social problem. Actually, a lot of poverty alleviation programs have been implemented by the municipal government of Surabaya. However, the program is still less effective because: 1) there is lack of coordination among agencies in running the program and 2) the program does not reflect the needs of the poor to a decent life in urban areas. This research employs qualitative method carried out in several governmental bodies relating to the issue of poverty alleviation. The result of this study indicates that there are eight priority needs of the poor, namely (1) education, (2) health, (3) housing, (4) nine basic needs, (5) clean water, (6) ease of administration, (7) training expertise, and (8) employment. From the eight priority needs of the poor, we found design of integrated program of poverty reduction which requires good coordination among relevant agencies. There are eight institutions which government agency should coordinate in the integrated program, namely (1) the Department of Education, (2) Social Service, (3) Departement of Health, (4) the Ministry of Community Empowerment, (5) Department of housing, planning, and urban development (6) Water Supply Company, (7) Department of Civil and Population, (8) the Ministry of Labour.
\end{abstract}

Keywords: integrated programme, poverty reduction, coordination, the priority needs of the poor

\begin{abstract}
Abstrak
Surabaya merupakan salah satu kota besar di Indonesia yang masih memiliki angka kemiskinan yang tinggi. Penelitian ini bertujuan untuk membuat desain program terpadu dalam penanggulangan kemiskinan di Kota Surabaya. Permasalahan kemiskinan ini menimbulkan masalah komplekss seperti pengangguran, pendidikan, kesehatan, kriminalitas, dan masalah sosial. Sebenarnya sudah banyak program penanggulangan kemiskinan yang dilaksanakan oleh pemkot Surabaya. Namun program tersebut masih kurang efektif karena: 1) tidak ada koordinasi antar instansi dalam menjalankan program dan 2) program tersebut tidak merefleksikan kebutuhan kelompok miskin untuk hidup layak di perkotaan. Penelitian menggunakan metode kualitatif dan dilaksanakan pada instansi-instansi yang terkait dengan program pengentasan kemiskinan di Kota Surabaya, yaitu Badan Perencanaan Pembangunan Kota (Bappeko), Bapemas dan KB, Dinas Koperasi dan UMKM, Disperindag, Dinas Kesehatan, Dinas Tenaga Kerja, Dinas Sosial, Dispendik dan PDAM. Teknik pengumpulan data dilakukan melalui 3 cara yaitu observasi, wawancara, dan dokumentasi. Hasil penelitian ini menunjukkan bahwa terdapat delapan prioritas kebutuhan kelompok miskin yaitu (1) pendidikan, (2) kesehatan, (3) perumahan, (4) sembilan kebutuhan pokok, (5) air bersih, (6) kemudahan administrasi, (7) pelatihan keahlian, dan (8) lapangan kerja. Dari kedelapan kebutuhan prioritas kelompok miskin tersebut ditemukan desain program terpadu penanggulangan kemiskinan yang mensyaratkan adanya koordinasi yang baik antar instansi terkait. Instansi yang harus melakukan koordinasi dalam program terpadu tersebut sejumlah delapan instansi yaitu (1) Dinas Pendidikan, (2) Dinas Sosial, (3) Dinas Kesehatan, (4) Bapemas dan KB, (5) Dinas Cipta Karya, (6) PDAM, (7) Dinas Kependudukan dan Catatan Sipil, (8) Dinas Tenaga Kerja.
\end{abstract}

Kata kunci: program terpadu, penanggulangan kemiskinan, koordinasi, kebutuhan prioritas kelompok miskin 


\section{Pendahuluan}

Surabaya merupakan salah satu kota besar di Indonesia yang masih memiliki angka kemiskinan yang tinggi. Berdasarkan data Badan Pusat Statistik (BPS) Kota Surabaya, jumlah penduduk miskin di kota Surabaya pada tahun 2009 sebanyak 171.200 jiwa, tahun 2010 sebanyak 195.700 jiwa, tahun 2011 sebanyak 183.300 jiwa, tahun 2012 sebanyak 175.100 jiwa, dan tahun 2013 sebanyak 168.690 jiwa. Apabila dilihat dari prosentase penduduk miskin terhadap total jumlah penduduk di Kota Surabaya, maka prosentase penduduk miskin di kota Surabaya pada tahun 2009 sebesar 6.72\%, tahun 2010 sebesar 7.07\%, tahun 2011 sebesar $6.58 \%$, tahun 2012 sebesar $6.23 \%$, tahun 2013 sebesar 5.97\%. Kemiskinan akan menimbulkan berbagai permasalahan yang kompleks di masyarakat. Banyaknya orang miskin yang menganggur atau hanya memiliki penghasilan yang kurang, akan menyebabkan orang miskin tidak dapat memenuhi kebutuhan dasar (basic need) keluarganya. Akibatnya, keluarga miskin menjadi kurang sehat atau sakit-sakitan karena kekurangan gizi dan nutrisi. Keluarga miskin juga akan mengalami kesulitan dalam mengakses pendidikan karena anak-anak mereka ikut mencari nafkah membantu beban keluarga. Akibat selanjutnya, banyak anak-anak dari keluarga miskin yang turun atau bahkan hidup di jalanan. Kemiskinan juga mengakibatkan kriminalitas yang terjadi sebagai akibat tidak tercukupinya kebutuhan hidup orang miskin yang memaksa mereka untuk melakukan tindakan kejahatan seperti mencuri, merampok, menipu yang seringkali diikuti dengan tindakan kekerasan. Akibat lebih jauh lagi dari masalah kemiskinan adalah masalah sosial, seperti tidak diterimanya kelompok miskin ini di masyarakat karena dianggap "mengganggu".

Kelompok miskin terbesar di Kota Surabaya berada di 3 Kecamatan, yaitu Kecamatan Semampir, Kecamatan Tambaksari, dan Kecamatan Simokerto. Kecamatan Semampir terdiri dari 5 kelurahan dengan $60.41 \%$ keluarga miskin, Tambaksari terdiri dari 6 kelurahan dengan $12.47 \%$ keluarga miskin, sedangkan kecamatan Simokerto terdiri dari 5 kelurahan dengan $41.82 \%$ keluarga miskin. Berikut, data prosentase keluarga miskin di Kecamatan Semampir, Tambaksari, dan Simokerto.

Tabel 1.

Prosentase keluarga miskin di Kecamatan Semampir, Tambaksari, Simokerto

\begin{tabular}{|c|c|c|c|c|}
\hline Kecamatan & Kelurahan & $\begin{array}{c}\text { Jumlah } \\
\text { Keluarga } \\
\text { Seluruhnya }\end{array}$ & $\begin{array}{c}\text { Jumlah } \\
\text { Keluarga } \\
\text { Miskin }\end{array}$ & $\begin{array}{c}\text { Prosentase } \\
(\%)\end{array}$ \\
\hline \multirow[t]{5}{*}{$1 \quad$ Semampir } & Ampel & 5.333 & 906 & 6,33 \\
\hline & Sidotopo & 8.271 & 4.937 & 13,21 \\
\hline & Pegirian & 6.610 & 3.561 & 10,17 \\
\hline & Wonokusumo & 12.244 & 5.887 & 18,13 \\
\hline & Ujung & 7.485 & 5.176 & 12,60 \\
\hline Jumlah & & 39.943 & 20.467 & 60,41 \\
\hline \multirow[t]{6}{*}{$\begin{array}{ll}2 & \text { Tambaksari }\end{array}$} & Pacarkeling & 7.559 & 1.537 & 20.33 \\
\hline & $\begin{array}{l}\text { Pacar } \\
\text { Kembang }\end{array}$ & 9.469 & 1.701 & 17.96 \\
\hline & Ploso & 6.376 & 2.016 & 31.62 \\
\hline & Tambaksari & 3.940 & 1.142 & 28.98 \\
\hline & Rangkah & 3.863 & 1.080 & 27.96 \\
\hline & Gading & 24.357 & 3.037 & 12.47 \\
\hline Jumlah & & 55.564 & 10.513 & 18.92 \\
\hline \multirow[t]{5}{*}{ Simokerto } & Kapasan & 16.980 & 692 & 4.07 \\
\hline & Tambak Rejo & 17.668 & 1.552 & 8.78 \\
\hline & Simokerto & 23.822 & 1.752 & 7.35 \\
\hline & Sidodadi & 16.080 & 1.682 & 10.46 \\
\hline & Simolawang & 22.108 & 2.468 & 11.16 \\
\hline Jumlah & & 96.658 & 8.146 & 41.82 \\
\hline
\end{tabular}

Sumber : BPS Jatim 2012

Dari tabel 1 terlihat bahwa 3 kelurahan dari masing-masing kecamatan yang memiliki angka kemiskinan tinggi adalah: 1) Kecamatan Semampir (Kelurahan Sidotopo, Kelurahan Wonokusumo, 
Kelurahan Ujung), 2) Kecamatan Tambaksari (Kelurahan Ploso, Kelurahan Tambaksari, Kelurahan Rangkah), dan 3) Kecamatan Simokerto (Kelurahan Tambak Rejo, Kelurahan Sidodadi, Kelurahan Simolawang).

Berbagai program penanggulangan kemiskinan sudah banyak dilakukan oleh Pemerintah kota Surabaya. Instansi terkait yang telah melaksanakan program pengentasan kemiskinan adalah Badan Pemberdayaan Masyarakat dan Keluarga Berencana/Bapemas KB, Dinas Koperasi dan UMKM, Dinas Perindustrian dan Perdagangan/Disperindag, Dinas Kesehatan/Dinkes, Dinas Tenaga Kerja/Disnaker, Dinas Sosial/Dinsos, dan Dinas Pendidikan/Dispendik.

Upaya penanggulangan kemiskinan tersebut terlihat masih belum efektif. Hal ini karena berbagai program kemiskinan yang dilaksanakan oleh Satuan Kerja Perangkat Daerah (SKPD) di Kota Surabaya tidak saling terkoordinasi. Akibatnya, program penanggulangan kemiskinan tidak terfokus pada satu arah. Banyak program yang dilaksanakan berbagai SKPD tersebut saling tumpang tindih atau overlapping dan tidak saling menunjang. Ada dua penyebab utama tidak efektifnya program penanggulangan kemiskinan, yaitu 1) tidak ada koordinasi antar SKPD dalam menjalankan program penanggulangan kemiskinan, dan 2) program penanggulangan kemiskinan tersebut masih belum merefleksikan kebutuhan kelompok miskin untuk hidup layak di perkotaan.

Diperlukan adanya program terpadu untuk penanggulangan kemiskinan di kota Surabaya. Program terpadu yang harus disediakan merupakan program yang disesuaikan dengan kebutuhan kelompok miskin dan memerlukan keterkaitan/koordinasi antar instansi, tanpa ada overlapping antar pelaksana program. Program terpadu yang harus disediakan tersebut adalah suatu program yang harus benarbenar sesuai dengan kebutuhan kelompok miskin untuk memenuhi basic need, sehingga bisa hidup layak.

Kelompok miskin di Kota Surabaya termasuk kategori kemiskinan perkotaan. Beban orang miskin di perkotaan akan lebih berat daripada beban orang miskin di perdesaan. Orang miskin perkotaan harus menghadapi persaingan hidup yang sangat keras di tengah-tengah pembangunan perkotaan. Orang miskin perkotaan akan kalah bersaing dalam kesempatan lapangan pekerjaan. Orang miskin perkotaan juga harus menanggung biaya hidup yang sangat mahal di kota. Oleh karena itu, kelompok miskin di perkotaan akan kesulitan memenuhi kebutuhan dasar (basic need) nya agar bisa hidup layak.

Penelitian ini bertujuan untuk mengetahui program terpadu penanggulangan kemiskinan apa sajakah yang paling sesuai bagi kelompok miskin di Kota Surabaya berdasar prioritas kebutuhan/basic need mereka untuk hidup layak.

\section{Metode Penelitian}

Jenis penelitian yang digunakan adalah penelitian kualitatif deskriptif. Pemilihan metode kualitatif karena penelitian ini mendeskripsikan bagaimana, kapan, di mana, dan suasana dari sesuatu yang diteliti (Berg 2000). Untuk mendapatkan data yang akurat dalam menjawab pertanyaan penelitian ini, maka telah dilakukan penelitian pada sembilan kelurahan yang memiliki angka kemiskinan tertinggi di Surabaya dan sembilan instansi yang memiliki program kemiskinan. Kesembilan kelurahan tersebut adalah Kelurahan Sidotopo, Wonokusumo, Ujung, Ploso, Tambaksari, Rangkah, Tambak Rejo, Sidodadi, Simolawang. Sedangkan instansi terkait adalah Badan Perencanaan Pembangunan Kota (Bappeko), Badan Pemberdayaan Masyarakat dan KB (Bapemas KB), Dinas Kesehatan (Dinkes), Dinas Tenaga Kerja (Disnaker), Dinas Sosial (Dinsos), Dinas Pendidikan (Dispendik), Dinas Catatan Sipil dan Kependudukan (Dispendukcapil), Dinas Cipta Karya, dan PDAM.

Teknik pengumpulan data dilakukan melalui 3 cara, yaitu observasi, wawancara, dan dokumentasi (Stake 2010). Observasi dilakukan dengan cara melihat kondisi masyarakat di sejumlah sembilan kelurahan yang dijadikan sebagai lokasi penelitian. Wawancara dilakukan dengan mengajukan pertanyaan terbuka kepada para informan dari masyarakat maupun dari instansi terkait. Informan dari 
masyarakat adalah para tokoh masyarakat setempat, sedangkan informan dari instansi terkait, yaitu Bappeko (staf perencanaan dan penyusunan program), Bapemas KB (kasi penguatan kelembagaan dan partisipasi masyarakat), Dinkes (kasi layanan khusus dan pelayanan kesehatan), Disnaker (kasi penempatan dan perluasan tenaga kerja), Dinsos (kasi penyandang masalah kesejahteraan sosial), Dispendik (staf bidang pendidikan layanan khusus), Dispendukcapil (staf bidang pencatatan sipil), Dinas Cipta Karya (staf seksi program dan perencanaan teknis), dan PDAM (staf penyusunan program).

Derajat kepercayaan pemeriksaan data dalam penelitian ini dilakukan dengan teknik triangulasi yaitu dengan cara membandingkan data hasil pengamatan dengan data hasil wawancara, dan membandingkan hasil wawancara dengan isi suatu dokumen yang berkaitan (Moleong 2008). Selain melakukan wawancara dengan masyarakat dan aparat instansi terkait, untuk mendapatkan informasi yang akurat dilakukan pula cross check terhadap dokumen resmi yang dimiliki instansi terkait serta pengamatan di lokasi penelitian.

\section{Hasil dan Pembahasan}

Hill (dalam Lister 2004), kemiskinan diartikan seseorang dapat membeli apa yang mereka butuhkan namun tidak mampu membeli benda yang kebanyakan orang dapat membeli atau mereka tidak bisa makan dan hidup tanpa mendapatkan hutang. Kemudian Bank Dunia mendefiniskan kemiskinan berdasarkan pendekatan konsumsi bahwa orang dapat dikatakan miskin jika seseorang tersebut tidak dapat membeli makanan sesuai dengan standar gizi yang diperlukan oleh anak-anak (dalam Gordon dkk. 2003). UU Nomor 17 Tahun 2007 Tentang Rencana Pembangunan Jangka Panjang Nasional Tahun 2005-2025 menyatakan bahwa masalah kemiskinan bersifat multidimensi. Kemiskinan bukan hanya menyangkut ukuran pendapatan, melainkan juga kerentanan dan kerawanan orang atau masyarakat untuk menjadi miskin. Selain itu, kemiskinan juga menyangkut kegagalan dalam pemenuhan hak dasar (basic needs) dan adanya perbedaan perlakuan seseorang atau kelompok masyarakat dalam menjalani kehidupan secara bermartabat. Selanjutnya Bappenas (dalam Jonaedi 2012) mendefinisikan kemiskinan secara lebih komprehensif, dengan melihat kemiskinan sebagai kondisi seseorang yang tidak mampu memenuhi hak-hak dasarnya untuk mempertahankan dan mengembangkan kehidupan yang bermartabat. Hak-hak dasar tersebut adalah kebutuhan pangan, kesehatan, pendidikan, pekerjaan, perumahan, air bersih, pertanahan, sumberdaya alam dan lingkungan hidup, rasa aman dari perlakukan atau ancaman tindak kekerasan dan hak untuk berpartisipasi dalam kehidupan sosial-politik.

Pendekatan kebutuhan dasar, melihat kemiskinan sebagai suatu ketidakmampuan (lack of capabilities) seseorang dalam memenuhi kebutuhan minimum seperti pangan, sandang, papan, pelayanan kesehatan, pendidikan, penyediaan air bersih dan sanitasi. Penelitian ini menunjukkan bahwa kebutuhan prioritas kelompok miskin yaitu: (1) pendidikan, (2) kesehatan, (3) perumahan, (4) sembilan bahan pokok, (5) air bersih, (6) kemudahan administrasi, (7) pelatihan keahlian, (8) lapangan pekerjaan. Dapat disimpulkan bahwa kelompok miskin menempatkan kebutuhan pendidikan, kesehatan, dan perumahan sebagai tiga prioritas kebutuhan teratas.

Untuk menanggulangi kemiskinan, pemerintah kota Surabaya telah melaksanakan berbagai program terutama yang berhubungan dengan 3 prioritas kebutuhan kelompok miskin yaitu program pendidikan, kesehatan, dan perumahan. Perserikatan Bangsa-Bangsa (PBB) dalam bukunya, Administration of Development Programs and Project, Some Major Issues, mengemukakan bahwa "Program adalah aktivitas sosial yang terorganisasi dengan tujuan tertentu dalam ruang dan waktu yang terbatas, yang terdiri dari berbagai proyek dan biasanya terbatas pada satu atau lebih organisasi atau aktivitas" (Tjokroamidjoyo 1990). Suatu program yang baik mempunyai ciri-ciri sebagai berikut (1) tujuan yang jelas, (2) penentuan peralatan yang terbaik untuk mencapai tujuan tersebut, (3) kerangka kebijaksanaan yang konsisten atau proyek-proyek yang saling berkaitan untuk mencapai tujuan program seefektif mungkin, (4) pengukuran cost benefit yang akan dihasilkan program tersebut, (5) hubungan dengan kegiatan atau program lainnya (Tjokroamidjoyo 1990). 
Dari penelitian ini, terlihat bahwa program pengentasan kemiskinan yang dilaksanakan oleh beberapa instansi tidak saling mendukung, bahkan terdapat tumpang tindih (overlapping). Hal ini memperlihatkan bahwa program penanggulangan kemiskinan masih belum memiliki tujuan yang jelas. Terdapat empat program yang dalam pelaksanaannya overlapping, yaitu: 1) Pemberdayaan Ekonomi bagi Keluarga Miskin oleh Bapemas overlapping dengan pelatihan handycraft, menjahit dan tata boga oleh Dinas Sosial. Kedua program tersebut pada intinya adalah sama yaitu memberikan pelatihan keterampilan seperti menjahit, membuat handycraft dan lain-lain yang sasarannya adalah perempuan keluarga miskin. 2) PMT atau Bantuan Makanan untuk Lansia yang dilakukan oleh Dinas Sosial overlapping dengan Program Pemberian Snack Lansia oleh Dinas Kesehatan. Pada dasarnya kedua program ini bertujuan sama yaitu perbaikan gizi pada Lansia. 3) Pendididikan Lanjutan Siswa Bermasalah Sosial oleh Disnaker overlapping dengan Peningkatan Kesejahteraan Sosial bagi PMKS Pondok Sosial Anak Wonorejo oleh Dinsos. Overlapping dalam pelaksanaan program ini terjadi karena memang tidak ada koordinasi antara kedua instansi karena kedua instansi memiliki kriteria tersendiri dalam penentuan Penyandang Masalah Kesejahteraan Sosial, sehingga sasaran dan target dari program ini tergantung masing-masing instansi. 4) Fasilitasi Pengembangan Kelompok Usaha Skala Mikro-kecil oleh Dinas Koperasi dan UMKM overlapping dengan Fasilitasi Pengembangan Hasil Usaha Ekonomi Mikro oleh Bapemas. Kedua program ini memiliki kegiatan yang sama yaitu menyewakan stan untuk membantu pemasaran hasil usaha skala mikro.

Penyebab overlapping program-program penanggulangan kemiskinan yang dilaksanakan oleh instansi terkait karena tidak adanya koordinasi. Untuk menanggulangi masalah kemiskinan di Kota Surabaya, setidaknya terdapat tujuh instansi yang terlibat yaitu: (1) Badan Pemberdayaan Masyarakat dan Keluarga Berencana, (2) Dinas Koperasi dan UMKM, (3) Dinas Perindustrian dan Perdaganagan, (4) Dinas Kesehatan, (5) Dinas Tenaga Kerja, (6) Dinas Sosial, dan (7) Dinas Pendidikan. Dalam mengatasi kemiskinan, beberapa instansi memiliki keterkaitan dengan instansi lain untuk melaksanakan beberapa programnya. Namun demikian, tidak semua instansi tersebut melakukan koordinasi meskipun programnya saling terkait. Pada tabel 2 menunjukkan keterkaitan instansi dalam menanggulangi kemiskinan di Kota Surabaya berdasarkan prioritas kebutuhan kelompok miskin.

Tabel 2.

Keterkaitan dan Koordinasi Program-Program Penanggulangan Kemiskinan Antar Instansi

\begin{tabular}{lllc}
\hline No & \multicolumn{1}{c}{ Instansi } & \multicolumn{1}{c}{ Instansi Terkait } & Koordinasi \\
\hline 1 & Bapemas dan KB & Dinas Koperasi dan UMKM & Ya \\
& & Disperindag & Ya \\
& & Dinas Sosial & Tidak \\
& & Dinas Tenaga Kerja & Tidak \\
& & Dinas Pendidikan & Ya \\
\hline 2 & Dinas Koperasi dan & Disperindag & Ya \\
& UMKM & Dinas Kesehatan & Tidak \\
& & Bapemas dan KB & Ya \\
\hline 3 & Dinas Perindustrian & Dinas Koperasi dan UMKM & Ya \\
& dan Perdagangan & Bapemas dan KB & Ya \\
\hline 4 & Dinas Sosial & Dinas Tenaga Kerja & Tidak \\
& & Bapemas dan KB & Tidak \\
& & Dinas Kesehatan & Tidak \\
\hline 5 & Dinas Tenaga Kerja & Dinas Pendidikan & Tidak \\
& & Bapemas dan KB & Tidak \\
& & Dinas Sosial & Tidak \\
\hline 6 & Dinas Pendidikan & Bapemas dan KB & Ya \\
& & Dinas Tenaga Kerja & Tidak \\
\hline 7 & Dinas Kesehatan & Dinas koperasi dan UMKM & Ya \\
& & Dinas Sosial & Ya \\
\hline
\end{tabular}

Sumber : hasil olah data 
Tabel 2 menunjukkan bahwa meskipun program penanggulangan yang dilaksanakan oleh suatu instansi selalu terkait dengan instansi yang lain, namun hampir sebagian besar tidak melakukan koordinasi. Hal ini yang menyebabkan seringnya terjadi overlapping program penanggulangan kemiskinan dan berakibat program tersebut kurang efektif.

Untuk itulah diperlukan program terpadu antar instansi agar penanggulangan kemiskinan menjadi efektif. Untuk mendapatkan program terpadu, salah satu syarat yang harus dipenuhi adalah adanya koordinasi antar pelaksana. Banyak ahli mendefinisikan pemahaman tentang koordinasi dengan memberi pendapat yang berbeda-beda tetapi mempunyai tujuan yang sama, yakni bahwa koordinasi adalah asas umum dalam semua organisasi atau dapat dikatakan koordinasi adalah asas pokok organisasi. Mooney (dalam Sutarto 1998) mengemukakan bahwa pengertian koordinasi adalah "The orderly arrangement of group effort, to provide unity of action in the pursuit of common purpose". Mooney memandang bahwa koordinasi merupakan suatu pengaturan usaha sekelompok orang secara teratur untuk menciptakan kesatuan tindakan dalam mengusahakan tercapainya suatu tujuan.

Pengaturan usaha kelompok atau organisasi memang diperlukan, mengingat organisasi terdiri atas sejumlah unit kerja yang berlainan fungsi namun diikat oleh satu kesatuan tujuan tertentu. Selaras dengan pendapat Mooney, Benn (dalam Sutarto 1998) mengatakan bahwa "Coordination: A Continuous, harmonious action toward the objectives, attained through leadership, organization, and administration; The arrangement of group efforts in a continuous and orderly manner so as to provide unification of action in the pursuit of a common goal". Dari pendapat tersebut diperoleh suatu konsep pemahaman bahwa koordinasi adalah suatu kelangsungan, keharmonisan mencapai tujuan, yang dapat dicapai melalui kepemimpinan, organisasi dan administrasi. Koordinasi juga dipandang sebagai suatu penyusunan usaha-usaha kelompok di dalam suatu kelangsungan dan keteraturan sikap sehingga menciptakan kesatuan tindakan dalam mengusahakan tercapainya tujuan bersama.

Dari hasil penelitian telah disusun program terpadu penanggulangan kemiskinan yang mensyaratkan adanya keterkaitan dan koordinasi antar instansi. Program terpadu ini disusun berdasarkan prioritas kebutuhan kelompok miskin yang disinkronisasikan dengan berbagai program baik yang telah dilaksanakan maupun berupa usulan dari masing-masing instansi. Tabel 3 adalah program-program yang telah teridentifikasi.

Tabel 3.

Program Terpadu Penanggulangan Kemiskinan Berdasar Kebutuhan Prioritas Kelompok Miskin

\begin{tabular}{|c|c|c|c|}
\hline No & $\begin{array}{l}\text { Prioritas } \\
\text { Kebutuhan }\end{array}$ & Instansi Terkait & Program \\
\hline 1 & Pendidikan & Dinas Pendidikan & $\begin{array}{l}\text { Bantuan Siswa Miskin (BSM) } \\
\text { Beasiswa sekolah perkapalan } \\
\text { Pembinaan SD, SMP dan SMA terbuka } \\
\text { Bantuan Pemberian Seragam dan Alat Tulis }\end{array}$ \\
\hline 2 & Kesehatan & $\begin{array}{l}\text { Dinas Kesehatan } \\
\text { Dinas Sosial } \\
\text { Bapemas dan KB }\end{array}$ & $\begin{array}{l}\text { Pelayanan Kesehatan Keluarga Miskin } \\
\text { (Jamkesmas Non Kuota) dan Jampersal } \\
\text { Khitan Masal Anak dari Keluarga Tidak Mampu } \\
\text { Penyediaan dan pelayanan alat kontrasepsi bagi } \\
\text { Gakin }\end{array}$ \\
\hline 3 & Perumahan & $\begin{array}{l}\text { Dinas Cipta Karya } \\
\text { Dinas Sosial }\end{array}$ & $\begin{array}{l}\text { Bedah Rumah / Rehabilitasi Rumah } \\
\text { Fasilitasi dan pendampingan lingkungan rumah }\end{array}$ \\
\hline 4 & $\begin{array}{l}\text { Sembilan Bahan } \\
\text { Pokok }\end{array}$ & $\begin{array}{l}\text { Bapemas dan KB } \\
\text { Dinas Sosial }\end{array}$ & $\begin{array}{l}\text { Tim Koordinasi Program Beras Miskin } \\
\text { Penyediaan bahan makan sehat bagi balita } \\
\text { keluarga miskin (protein telur) }\end{array}$ \\
\hline 5 & Air bersih & PDAM & Penyediaan air bersih \\
\hline 6 & $\begin{array}{l}\text { Kemudahan } \\
\text { Administrasi }\end{array}$ & $\begin{array}{l}\text { Dinas } \\
\text { Kependudukan } \\
\text { dan Catatan Sipil }\end{array}$ & Fasilitas pengurusan akte kelahiran \\
\hline 7 & $\begin{array}{l}\text { Pelatihan } \\
\text { Keahlian }\end{array}$ & Bapemas dan KB & $\begin{array}{l}\text { Pembinaan Kemampuan dan Keterampilan Kerja } \\
\text { Keluarga Miskin }\end{array}$ \\
\hline
\end{tabular}




\begin{tabular}{llll}
\hline 8 & Lapangan kerja & $\begin{array}{l}\text { Dinas Tenaga } \\
\text { Kerja }\end{array}$ & $\begin{array}{l}\text { Pendampingan dan Pemilihan Bidang Kerja Bagi } \\
\text { Calon Lulusan SMA / SMK / MA kelompok miskin }\end{array}$ \\
\hline
\end{tabular}

Sumber: Hasil olah data

Dari tabel 3 bisa dijelaskan bahwa program terpadu penanggulangan kemiskinan di Kota Surabaya dilaksanakan oleh sejumlah delapan instansi terkait sebagai berikut:

1) Prioritas kebutuhan pendidikan; terdapat empat program dengan rincian program dilaksanakan oleh Dinas Pendidikan dan satu program dilaksanakan oleh Dinas Sosial. 2) Prioritas kebutuhan kesehatan; terdapat tiga program yang masing-masing dilaksanakan oleh Dinas Kesehatan, Dinas Sosial, Bapemas dan KB. 3) Prioritas kebutuhan perumahan; terdapat dua program yang masing-masing dilaksanakan oleh Dinas Cipta Karya dan Dinas Sosial. 4) Prioritas kebutuhan sembilan bahan pokok; terdapat dua program yang masing-masing dilaksanakan oleh Bapemas dan KB dan Dinas Sosial. 5) Prioritas kebutuhan air bersih; terdapat satu program yang dilaksanakan oleh PDAM. 6) Prioritas kebutuhan kemudahan administrasi; terdapat satu program yang dilaksanakan oleh Dinas Kependudukan dan Catatan Sipil. 7) Prioritas kebutuhan pelatihan keahlian; terdapat satu program yang dilaksanakan oleh Bapemas dan KB. 8) Prioritas kebutuhan lapangan kerja; terdapat satu program yang dilaksanakan oleh Dinas Tenaga Kerja.

\section{Simpulan}

Penanggulangan kemiskinan di Kota Surabaya bisa efektif terlaksana bila menggunakan program terpadu. Tiap-tiap instansi di Kota Surabaya merancang program-program penanggulangan kemiskinan yang memiliki keterkaitan dan koordinasi dengan instansi lain. Program tersebut juga harus disesuaikan dengan prioritas kebutuhan kelompok miskin untuk bisa hidup layak di perkotaan. Terdapat beberapa hal yang menjadi dasar pembuatan program terpadu penanggulangan kemiskinan yaitu: Melakukan need assessment terhadap basic need/kebutuhan prioritas kelompok miskin untuk dijadikan sebagai usulan program. Sinkronisasi/melakukan pemetaan masing-masing program dengan instansi terkait. Beberapa program yang overlapping harus dipangkas dan dilaksanakan oleh instansi yang benar-benar memenuhi kriteria sebagai pelaksana. Melakukan koordinasi antar instansi terkait mulai dari perencanaan program, pelaksanaan, hingga evaluasi program.

\section{Daftar Pustaka}

Jonaidi A (2012) Analisis pertumbuhan ekonomi dan kemiskinan di indonesia. Jurnal Kajian Ekonomi 1 (1):140-164.

Berg BL (2000) Qualitative Research Methods for The Social Sciences: Seventh Edition. Sydney: Allyn and Bacon.

Gordon D, Nandy S, Pantazis C, Pemberton S dan Townsend P (2003) Child Poverty in the Developing World. UK: The Policy Press.

Moleong LJ (2008) Metodologi Penelitian Kualitatif. Bandung: Remaja. Rosdakarya.

Lister R (2004) Poverty. Cambridge: Polity Press.

Stake R (2010) Qualitative Research. New York: The Guilford Press A Division of Guilford Publications, Inc.

Sutarto (1998) Dasar-Dasar Kepemimpinan Administrasi. Yogyakarta: Gajah Mada University Press. Tjokroamidjojo B (1990) Perencanaan Pembangunan. Jakarta: Gunung Agung.

UU Nomor 17 Tahun 2007 Tentang Rencana Pembangunan Jangka Panjang Nasional Tahun 20052025 . 